JAMP: Jurnal Adminitrasi dan Manajemen Pendidikan

Volume 3 Nomor 4 Desember 2020, Hal : 320-331

Tersedia Online di http://journal2.um.ac.id/index.php/jamp/

ISSN 2615-8574 (online)

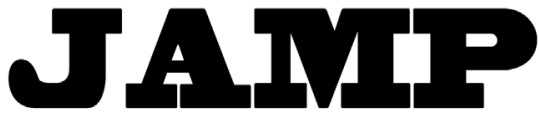

JURNAL ADMINISTRASI DAN MANAJEMEN PENDIDIKAN

\title{
INTERNALISASI NILAI-NILAI PESANTREN BERBASIS MANAJEMEN ASRAMA
}

\author{
Djamaluddin Perawironegoro \\ Hendro Widodo \\ Wantini \\ Muhammad Lailan Arqam \\ Magister Pendidikan Agama Islam, Universitas Ahmad Dahlan Yogyakarta \\ Jl. Pramuka No. 42 Sidikan Umbulharjo Yogyakarta \\ E-mail: djamaluddin@mpai.uad.ac.id / 085669045290
}

\begin{abstract}
Character education is still the main problem in national education, Pesantren as Islamic educational institution with a long history in realizing the goal of national education is still strong. The excellence of Pesantren in the aspect of internalizing Islamic values that is comprehensively designed relevant with local traditions. In general, they only held general activities with the intention of being limited to the program's implementation. Until this stage, they do not yet have an effective method of internalization. This study aims to find and develop boarding school internalization methods based on boarding management. The method used is a qualitative approach case study type. The results showed that the internalization of Pesantren values was carried out through hostel management with planning, organizing, actuating, and evaluating daily activities that took place at the hostel. The values reflected in the sustainability activities at the hostel were orderly and implemented with full responsibility by the board hostel and students. Internalization of values managed by the hostel management approach becomes an effective and efficient means of achieving Pesantren goals.
\end{abstract}

Keywords: internalization of value; hostel management; pesantren management

\begin{abstract}
Abstrak: Pendidikan karakter masih menjadi problem pokok dalam pendidikan nasional, Pesantren masih kukuh sebagai lembaga pendidikan Islam dengan sejarah yang panjang dalam mewujudkan tujuan pendidikan nasional. Keunggulan pendidikan pesantren pada aspek internalisasi nilai-nilai Islam yang didesain secara komprehensif relevan dengan tradisi lokal. Pada umumnya Pesantren menyelenggarakan kegiatan normatif dengan maksud terbatas pada keterlaksanaan program. Sampai pada tahapan ini, pesantren belum memiliki metode internalisasi nilai yang efektif. Penelitian ini bertujuan untuk menemukan dan mengembangkan metode internalisasi pesantren berbasis manajemen asrama. Metode penelitian yang digunakan adalah dengan pendekatan kualitatif jenis studi kasus. Hasil penelitian menunjukkan bahwa internalisasi nilai-nilai pesantren dilakukan melalui manajemen asrama dengan perencanaan, pelaksanaan, pengorganisasian, dan evaluasi kegiatan-kegiatan harian yang berlangsung di asrama. Nilai-nilai pesantren direfleksikan dalam keberlangsungan kegiatan-kegiatan di asrama yang tertib dan dilaksanakan dengan penuh tanggungjawab oleh pengurus asrama dan santri. Internalisasi nilai-nilai yang dikelola dengan pendekatan manajemen asrama menjadi sarana yang efektif dan efisien dalam mencapai tujuan pesantren.
\end{abstract}

Kata kunci: Internalisasi nilai; manajemen asrama; manajemen pesantren

Internalisasi nilai-nilai luhur atau pendidikan karakter masih merupakan problem yang tidak pernah selesai. Berbagai paradigma masyarakat modern; hedonism, pragmatism, idealism, sosialisme, dan faham keagamaan turut memberikan warna pada nilai-nilai yang diserap oleh masyarakat. Berbagai faham tersebut semakin marak disosialisasikan melalui media sosial dengan berbagai bentuk instrumennya. 
Dampaknya adalah bias rule model dari mulai penggiat media sosial, kyai, ustadz, artis, dan bahkan figur dadakan yang mendadak popular. Dari yang nampak tersebut memancing masyarakat untuk meniru berbagai hal dari aspek yang nampak busana, gaya, cara bicara, sampai pada yang tidak nampak dalam bentuk nilai-nilai dan keyakinan yang dibawa oleh public figure. Pesantren menjadi tempat yang paling kondusif menurut orang tua untuk memberikan nilai-nilai dan ajaran agama, pengetahuan dasar, prilaku dasar, bagi peserta didik. Yang demikian itu sekaligus menjadi suatu sistem filter menghadapi berbagai problem masyarakat modern. Mastuhu (1994) mengungkapkan keunggulan pesantren dalam pola membangun karakter santri dengan prinsip-prinsip; theosentris, sukarela mengabdi, kearifan, kesederhanaan, kolektivitas, mengatur kegiatan bersama, ukhuwwah diniyyah, dan kebebasan (Mastuhu, 1994). Berbagai prinsip tersebut dimanifestasikan dalam setiap kegiatan di pesantren melalui lima unsur pesantren yang utama; Kyai, Santri, Kitab kuning, Masjid, dan Asrama (Dhofier, 2011). Berbagai penelitian telah dilakukan terkait dengan kyai (Mardiyah, 2012; Afandi, 2013; Arifin, 2015; Kesuma, 2017), santri (Nashori, 2011; Sri Wahyuni Tanshzil, 2012; Setiawan, 2013), kitab kuning (Bruinessen, 1999; Thoriqussu 'ud, 2012; Hanani, 2017; Rasyidin, 2017; Rijal, 2017; Sufa, 2017; Akbar and Ismail, 2018), nilai-nilai pesantren(Dahlan, 2016; Syafe'i, 2017; Masrur, 2018; Pertiwi et al., 2018), dan asrama (Syarifuddin, Mardianto, 2017; Perawironegoro, 2019; Tampubolon, 2019).

Penelitian ini fokus pada internalisasi nilai-nilai pesantren berbasis manajemen asrama. Menurut Tafsir (2010) internalisasi nilai merupakan suatu proses memberikan pengetahuan, teladan, perbuatan dan praktik dalam kehidupan (Tafsir, 2010). Pendidikan karakter sebagai proses pendidikan yang menekankan pada internalisasi nilai-nilai positif yaitu al-akhlaq al-kariimah pada setiap anak didik melalui berbagai kegiatan yang bersifat kognitif, afektif, dan psikomotorik (Isnaini, 2013). Internalisasi nilai-nilai pendidikan dalam perspektif pesantren terdiri dari nilai karakter personal yaitu jujur dan cerdas, dan karakter sosial tangguh dan peduli. Internalisasi tersebut tidak berhenti pada aspek teori, tetapi juga pada aspek praktek (Dahlan, 2016).

Tafsir (2010) mengungkapkan bahwa metode internalisasi nilai yang meliputi tiga tahapan; a) knowing; b) doing; dan c) being. Dijelaskan bahwa upaya memasukkan pengetahuan (knowing) dan keterampilan melaksanakan (doing) ke dalam pribadi, demikian itu disebut dengan upaya internalisasi atau personalisasi. Secara praktik, kegiatan internalisasi dilakukan dengan model keteladanan, pembiasaan, dan lain-lain yang biasa dilakukan oleh pendidik untuk memberikan pengetahuan, teladan perbuatan, dan praktik dalam kehidupan (Tafsir, 2010). Suriasumantri (2017) mengemukakan keterkaitan hubungan antara pengetahuan, sikap, dan prilaku. Disampaikan bahwa pengetahuan memiliki tiga ranah yaitu kognisi, afeksi, dan psikomotorik. Demikian juga sikap yang memiliki tiga ranah yakni kognisi, afeksi, dan konasi (kecenderungan bertindak). Aspek afektif dalam sikap memiliki proporsi yang lebih besar daripada pengetahuan, sehingga untuk membentuk sikap diperlukan lebih dari sekedar pengetahuan. Setelah sikap terbentuk, tahap berikutnya adalah aktualisasi sikap untuk menjadi prilaku, yaitu melalui dua titik strategis yaitu; a) pengorganisasian nilai; dan b) pembentukan kondisi objektif (Suriasumantri, 2017). Muhaimin (2005) mengutip pendapat Lickona yang mengungkapkan pembinaan terpadu dan timbal balik dari tiga dimensi moral yaitu moral knowing, moral feeling, and moral action. Pada sisi pengetahuan moral diketahui melalui kesadaran moral, pengetahuan nilai-nilai moral, mengambil perspektif, alasan moral, mengambil keputusan, dan pengetahuan diri. Pada bagian rasa moral ditunjukkan dengan rasa; kesadaran, menghargai diri, empati, mencintai yang baik, pengendalian diri, dan kerendahan hati. Berikutnya tindakan moral dapat diketahui dari kompetensi, kemauan, dan kebiasaan (Muhaimin, 2005).

Berdasarkan pendapat para ahli tersebut dapat dipahami bahwa internalisasi nilai merupakan proses yang panjang dari pengetahuan nilai, pertimbangan nilai-nilai yang relevan dengan asumsi diri, perbuatan nilai, dan habituasi nilai. Tahapan-tahapan internalisasi nilai ini berlaku bagi individu yang mendapatkan doktrin, ajaran, kegiatan, dan aktivitas dalam pola pendidikan. Sedangkan bagi pendidik upaya yang dilakukan adalah mengorganisasikan nilai-nilai melalui kegiatan yang relevan dengan daya perkembangan peserta didik.

Umami dan Amrulloh (2017) mengemukakan internalisasi nilai-nilai pendidikan di pesantren melalui proses pemberian pendidikan, pembentukan ahklak dengan pembiasaan shalat berjama'ah, 
dan membersihkan lingkungan (Umami and Amrulloh, 2017). Pembelajaran Pendidikan Agama Islam dalam bentuk kurikulum, silabus, rencana pelaksanaan pembelajaran, kegiatan intrakulikuler, dan ekstrakulikuler menjadi bagian bagi proses internalisasi nilai-nilai karakter, dengan proses tersebut peserta didik memiliki kompetensi bidang akademik dan berkarakter (Wibowo, 2014). Internalisasi karakter berbasis kurikulum di pesantren dilakukan melalui proses pembelajaran, budaya sekolah, kedisiplinan, pembiasaan melalui manajemen pesantren yang terintegrasi (Ma'arif and Rofiq, 2018). Senada dengan hal tersebut disampaikan Chandra (2019) yang mengemukakan proses internalisasi melalui pembiasaan, penanaman pengetahuan, pemahaman pengetahuan, berbuat baik, dan menjadi teladan yang baik, Adapun metode yang digunakan adalah dengan memberi pelajaran dan nasihat, pembiasaan akhlak yang baik, reward and punishment, dan keteladanan (Chandra, 2019).

Demikian itu dapat difahami sebagaimana pendapat Schein (2004) yang menyatakan bahwa setiap kelompok akan merefleksikan kepercayaan dan nilai-nilai dari seseorang yang ada di dalamnya. Nilainilai dari seseorang yang ada di dalamnya. Nilai-nilai yang dianut oleh warga organisasi merupakan nilai yang telah divalidasi secara sosial (social validation). Lebih lanjut, nilai-nilai yang akan diambil oleh warga organisasi adalah nilai-nilai yang tidak bertentangan dengan asumsi-asumsi dasar yang dibangun dari asumsi adaptasi eksternal, integrasi internal, realitas dan kebenaran, sifat waktu, sifat ruang, sifat manusia, sifat aktifitas manusia, dan sifat hubungan sesama manusia (Schein, 2004). Upaya pimpinan pesantren dalam menjaga nilai-nilai pesantren dilakukan dengan melakukan seleksi sumber daya manusia yang terlibat di pesantren, sosialisasi nilai-nilai pesantren, dan tindakan pengelola pesantren (Mardiyah, 2012). Pendekatan yang disampaikan lebih cenderung pada personifikasi figur kyai dan pimpinan unit-unit lembaga dalam mentransformasikan nilai-nilai pesantren. Senada dengan hal tersebut yaitu diungkapkan Masrur (2017) yang menyampaikan pendidikan karakter di pondok pesantren yang berorientasi dari Kyai (Masrur, 2018).

Berbeda dengan hal tersebut, yaitu Perawironegoro (2018) menyebutkan suatu temuan sistem organisasi pesantren yang terdiri dari struktur organisasi, budaya organisasi, manajemen sumber daya manusia yang berhubungan dengan efektifitas organisasi atau tujuan pesantren (Perawironegoro, 2018). Dengan kata lain bahwa, pesantren sebagai suatu sistem organisasi menghendaki kesiapan subsistemsubsistem pesantren. Tujuan pesantren yang adalah membentuk manusia yang berkarakter dan bernilai dapat dicapai pada saat pesantren mampu meberdayakan subsistem yang dimiliki secara optimal. Salah satu subsistem struktur organisasi pesantren adalah asrama. Sistem asrama menjadi sesuatu yang tidak dapat dihindari untuk dioptimalkan dalam rangka mencapai tujuan pesantren. Internalisasi nilai-nilai pesantren menjadi penting secara internal yaitu sebagai bekal santri dalam bekerjasama di dalam pesantren, sedangkan secara eksternal menjadi bekal karakter untuk kehidupan di masyarakat.

Berdasarkan pemaparan tersebut, nampak jelas bahwa hakikatnya pendidikan pesantren tidak pernah terlepas dari proses pembentukan karakter atau internalisasi nilai-nilai. Keragaman nilai-nilai yang berkembang di pesantren terletak pada fokus nilai-nilai yang dipilih oleh pimpinan pengelola pesantren. Sekalipun beragam, dapat disimpulkan bahwa semua pesantren memiliki fokus untuk menginternalisasikan nilai-nilai yang baik. Demikian itu sebagai media untuk mengeratkan hubungan kekerabatan, kekeluargaan, kebersamaan, dan kerjasama antara warga pesantren.

Kendala dari internalisasi nilai-nilai di asrama pesantren yaitu ragam karakter santri, frekwensi perpulangan santri, pergaulan di luar pesantren, media informasi yang diakses oleh para santri, dan faktor tradisi keluarga. Sekalipun ada kendala, terdapat faktor pendukung yaitu; keterlibatan santri dalam kegiatan, niat baik santri untuk memperbaiki diri, dorongan keluarga, keteladanan ustadz dan ustadzah, dan desain penciptaan lingkungan di pondok. Asrama dapat menjadi kekuatan untuk menginternalisasikan nilai-nilai, tetapi juga terdapat kendala di asrama yang menjadi tantangan bagi pengurus asrama (Umami and Amrulloh, 2017).

Riskiyah dan Muzammil (2020) mengungkapkan pesantren sebagai lembaga pendidikan merupakan tempat yang terbaik dalam membentuk karakater, nilai-nilai yang dikembangkan di pesantren yaitu; nilai aqidah, ibadah, akhlak, dan kemasyarakatan (Riskiyah and Muzammil, 2020). Dengan alasan bahwa penggunaan sistem asrama yang memungkinkan untuk menerapkan nilai-nilai dan pandangan 
dunia yang dianut dalam kehidupan sehari-hari. Untuk menginternalisasikan nilai-nilai pesantren, penting dalam pengelolaan asrama menggunakan pendekatan manajemen, kegiatan manajerial dilakukan dari proses perencanaan, pengorganisasian, penggerakan, dan pengawasan (Perawironegoro, 2019). Demikian itu selaras dengan pendapat Qomar (2007) yang menegaskan bahwa aspek penerapan manajemen pada lembaga pendidikan pesantren mengimplementasikan fungsi-fungsi manajemen yang terdiri dari perencanaan, pengorganisasian, penggerakan, dan pengawasan (Qomar, 2007). Drucker (2008) menegaskan urgensi manajemen bagi suatu institusi, "without the institution, there would be no management, but without management there would be only mob rather an institution"(Drucker, 2008). Di sini dimaksudkan bahwa sinergi antara institusi dengan manajemen sebagai suatu keharusan. Tanpa manajemen, institusi hanya sekumpulan manusia, sedangkan tanpa institusi tidak mungkin terjadi proses manajerial, terlebih mencapai tujuan bersama.

Dari berbagai latar belakang tersebut, penelitian ini merupakan penelitian baru dalam bidang internalisasi nilai-nilai pesantren berbasis manajemen pesantren, lebih khusus manajemen asrama. Penelitian ini bertujuan untuk menemukan dan mengembangkan suatu pola internalisasi nilai-nilai pesantren berbasis manajemen asrama. Desain pola ini memberikan alternatif pendekatan sistem dalam menginternalisasikan nilai-nilai pesantren, daripada pendekatan figur kyai. Selain itu juga akan meningkatkan efektifitas pengurus dalam menginternalisasikan nilai-nilai pesantren di asrama. Efektifitas tersebut akan nampak pada harmoni dan keselarasan satu kegiatan pondok dengan berbagai kegiatan pesantren yang lain, yang didesain dalam bentuk penciptaan lingkungan yang kondusif dan saling mendukung satu sama lain.

\section{METODE}

Penelitian ini menggunakan pendekatan penelitian kualitatif, yaitu sebagaimana diungkapkan Cresswell (2014) adalah suatu metode penelitian yang digunakan untuk mengeksplorasi dan memahami makna dari masalah sosial dan kemanusiaan (Cresswell, 2014). Sedangkan jenis penelitian yang digunakan adalah jenis penelitian studi kasus, yaitu jenis penelitian yang obyeknya berlingkup kecil, dicermati secara mendalam dan menyeluruh, termasuk konteks lingkungan, dan faktor-faktor yang terkait dengannya dalam rangka mendapatkan makna di balik obyek penelitian (Bawani, 2016). Pendekatan dan jenis penelitian ini dipilih untuk membantu peneliti memahami secara komprehensif makna dari proses internalisasi nilai-nilai pesantren yang terjadi di asrama melalui tindakan manajerial. Penelitian ini dilakukan pada bulan April hingga November 2019 di Pondok Modern Darul Arqam Patean Kendal.

Sumber data adalah situasi sosial yang terjadi di asrama yang meliputi pengurus asrama, para santri, dan aktifitas-aktifitas yang ada di asrama. Pengumpulan data dilakukan melalui proses wawancara kepada para santri, pengurus OSDA, musyrif/musyrifah, dan guru. Pemilihan informan dilakukan dengan cara purposed random sampling, yaitu memilih orang-orang tertentu dengan tujuan tertentu. Pemilihan tersebut dilakukan dengan melihat pengetahuan dan status informan di pesantren. Selain wawancara secara juga dilakukan observasi untuk mendapatkan gambaran asrama dan pengelolaannya, dan dokumentasi yaitu mengamati dan menganalisa dokumen. Sedangkan teknik analisis data melalui tahapan-tahapan pengumpulan data, menata data, mengelompokkan data, dan mensintesiskan dengan kajian teori yang telah dikutip peneliti pada pembahasan tinjauan pustaka.

\section{HASIL}

\section{Perencanaan Nilai-nilai Pesantren di Asrama}

Berdasarkan observasi dan dokumentasi didapati visi, misi, dan upaya mencapai tujuan yang diharapkan. Visi yang ingin dicapai pesantren Darul Arqam Patean Kendal adalah "Ketaqwaan, intelektual, kemandirian, kepeloporan, amar ma'ruf dan nahi munkar yang berdasarkan dari al-Qur'an dan as-Sunnah". Visi tersebut diturunkan menjadi misi pesantren, yaitu; 1) Mengembangkan dan membina semangat keunggulan secara intensif; 2) Memberikan bekal pemahaman dasar agama; 3) Memperkokoh landasan ketaqwaan dalam mewujudkan kesalehan pribadi dan sosial dijiwai semangat 
amar ma'ruf dan nahi munkar; 4) mempertajam semangat kepeloporan yang didukung fondasi keilmuan, dan intelektual yang memadai; dan 5) Membangun semangat hidup mandiri dengan bekal keterampilan yang dapat diandalkan.

Untuk mencapai visi-misi tersebut dirumuskan tindakan-tindakan terarah yang dilakukan warga pesantren melalui apa yang disebut dengan "Tiga Pilar Pondok", yaitu keteladanan, usaha untuk berakhlaq mulia dan memberi manfaat kepada orang lain, dan bersungguh-sungguh dalam setipa pekerjaan. Selain daripada itu, pondok juga merumuskan Sembilan Kebiasaan Sehari-hari atau disebut dengan "9 Golden Habit", yaitu; 1) Shalat wajib di awal waktu dengan berjama'ah diikuti dengan shalat-sahalat rawatib, tahajuud, dan shalat dhuha; 2) Mengerjakan puasa wajib dan diiringi dengan puasa sunnah; 3) Mengeluarkan infaq tiap bulan minimal 2,5\% dari uang yang masuk; 4) Mengusahakan tadarus 1 hari 1 juz (one day, one juz) dan mempelajari kandungannya; 5) Membiasakan membaca buku bacaan yang serius sehari minimal 1 jam; 6) Menjaga adab Islami dalam pergaulan muda-mudi, dengan orang tua, dalam berpakaian, dan memulai berbagai aktifitas dengan Bismillah; 7) Membiasakan untuk mengaji dan senantiasa berada dalam komunitas orang-orang shaleh; 8) Membiasakan berkata baik, beramal shaleh, dan memberikan manfaat bagi orang lain; dan 9) Berfikir positif dan murah senyum.

Visi-misi, Tiga Pilar Pondok, dan 9 Golden Habit merupakan panduan bagi seluruh warga pesantren dalam melakukan berbagai kegiatan, dan juga tujuan yang hendak dicapai. Semua itu disosialisasikan dalam berbagai acara pesantren dan dituliskan pada berbagai tempat untuk dibaca, diketahui, dan diamalkan dalam kehidupan sehari-hari. Pengetahuan terhadap hal pokok ini memberikan pedoman dalam berinteraksi, bekerjasama, berjuang, dan evaluasi diri juga organisasi. Berbagai hal tersebut juga menjadi landasan bagi unit-unit kerja, organisasi, asrama, berbagai kelompok-kelompok sekolah, minat dan bakat, dan kedaerahan.

Slogan yang memuat falsafah pesantren bersumber dari pengetahuan para santri yang didapatkan dari pengajaran dan pembelajaran di dalam kelas. Di dalam kelas, para santri mendapatkan pembelajaran dari guru-guru yang mengajarkan mata pelajaran Al-Qur'an, Hadits, Tafsir, dan Mahfudzat. Dalam pembelajaran al-Qur'an, selain guru membacakan ayat-ayat al-Qur'an untuk diikuti makhraj dan tajwidnya, guru-guru juga menjelaskan makna yang terkandung di dalam ayat-ayat tersebut, yang relevan dengan kehidupan sehari-hari. Pada pembelajaran Hadits memuat hadits-hadits yang bertemakan akhlaq kepada sesama, saudara yang lebih tua, guru, dan orang tua. Tafsir adalah pilihan ayat-ayat tertentu yang selaras dengan nilai-nilai pondok. Sedangkan Mahfudzat, berisikan bait-bait puisi yang memuat sikap diri, wibawa, keberanian, motivasi, prilaku sesama, baik dan buruk, dan banyak hal tentang akhlaq yang baik.

Di asrama-asrama santri, nilai-nilai dan falsafah pesantren dikembangkan dalam bentuk sosialisasi melalui slogan-slogan yang diletakkan di dinding-dinding asrama. Selain berfungsi untuk mensosialisasikan nilai-nilai dan falsafah, juga memberikan unsur keindahan, kreatifitas santri, dan kecakapan dalam "menghidupkan" asrama sesuai dengan fungsi-fungsinya. Ada satu kamar menuliskan dan menempelkan 99 Asma' al-husna di dinding dalam kamar. Pada kamar lain dituliskan "Cukuplan kematian sebagai pengingat, keyakinan sebagai kekayaan, dan ibadah sebagai kesibukan", "Jadikan alQur'an sebagai pedoman", "Sukses itu butuh kerja kelas, modal, pikiran, dan ketekunan", dan masih banyak lagi slogan-slogan yang memuat falsafah hidup untuk memotivasi para santri agar mencapai tujuan pesantren.

Nilai-nilai dan falsafah yang diungkapkan dalam bentuk slogan dirumuskan secara bersama-sama oleh pengurus asrama, pengurus kamar, dan warga kamar. Pada prinsipnya ketua asrama atau ketua kamar mengungkapkan satu ide gagasan tentang slogan yang akan disosialisasikan berdasarkan asumsi kehidupan di asrama pada tahun-tahun yang lalu, yang kemudian asumsi tersebut bertemu dengan slogan yang didapatkan dari pembelajaran di kelas atau nasehat yang diberikan pengasuh dan guru-guru, dan kemudian sesuai untuk disampaikan kepada para santri sebagai bekal dalam hidup bersama-sama di asrama.

Para santri memiliki pengetahuan tentang kebutuhan untuk "menghidupkan" lingkungan kamar atau asrama yang mungkin akan menjenuhkan dengan berbagai kegiatan sehari-hari selama 24 jam dalam 
satu tahun. Oleh karena itu santri yang tinggal di kamar memilih dan memilah slogan atau falsafah apa yang dibutuhkan untuk selalu dibaca dan memotivasi pembaca untuk berkontribusi aktif dalam kegiatan di asrama. Agar kecenderungan untuk saling bekerjasama, saling membantu satu sama lain, memberi dan berbagi dalam kondisi ada dan tidak ada. Nilai-nilai yang disosialisasikan di asrama adalah kebersihan, kebersamaan, keamanan, kedisiplinan, ketertiban, saling nasehat dan menasehati.

Wawancara dengan salah satu musyrifah menyampaikan "Nilai-nilai pesantren harus dimiliki dan dilakukan oleh para santri adalah sopan santun kepada kakak kelas, rajin dalam beribadah, semangat dalam belajar, dan menjalankan pekerjaan di pondok". Demikian itu dapat diketahui bahwa nilai-nilai pesantren benar-benar masuk kepada para pengurus, dan juga disosialisasikan kepada warga pesantren, melalui kegiatan-kegiatan di asrama. Tujuan dari nilai-nilai pesantren disosialisasikan adalah agar para santri membiasakan diri untuk berakhlaqul karimah yang diwujudkan dalam sikap sopan, santun, tertib, dan disiplin. Selain itu, nilai-nilai tersebut berfungsi untuk mengatur dan menjadi panduan untuk hidup bersama santri-santri yang lain dengan keragaman latar belakang, agar mau bekerjasama dalam menjaga lingkungan asrama yang membuat nyaman warga pesantren.

\section{Pengorganisasian nilai-nilai Pesantren di Asrama}

Nilai-nilai yang diyakini bersama oleh warga pesantren disosialisasikan oleh para pengurus, yaitu; kyai, guru-guru, staff pengasuhan santri, pengurus Organisasi Santri Darul Arqam (OSDA), mudabbir/ ah, musyrif/ah dan ketua kamar. Terkait dengan kehidupan di asrama kyai, staff pengasuhan santri, pengurus OSDA, mudabbir/ah, musyrif/ah, dan ketua kamar memiliki keterkaitan yang erat dengan kehidupan di asrama.

Para santri memiliki pengetahuan tentang kebutuhan untuk "menghidupkan" lingkungan kamar atau asrama yang mungkin akan menjenuhkan dengan berbagai kegiatan sehari-hari selama 24 jam dalam satu tahun. Oleh karena itu santri yang tinggal di kamar memilih dan memilah slogan atau falsafah apa yang dibutuhkan untuk selalu dibaca dan memotivasi pembaca untuk berkontribusi aktif dalam kegiatan di asrama. Agar kecenderungan untuk saling bekerjasama, saling membantu satu sama lain, memberi dan berbagi dalam kondisi ada dan tidak ada, selalu ada dalam diri warga asrama.

Kyai memiliki peranan dalam menginternalisasikan nilai-nilai pesantren di asrama yaitu melalui kegiatan tawshiyah setelah shalat fardhu atau sewaktu-waktu datang ke asrama secara langsung. Kehadiran kyai berfungsi untuk memberikan pengetahuan dan menjadi teladan bagi para santri untuk senantiasa hidup damai, tertib, bersih, dan penuh kedisiplinan. Nilai-nilai yang disampaikan adalah nilai-nilai kepesantrenan secara umum dalam rangka menjaga para santri agar betah di pesantren, mampu menjalankan tugas dan fungsi sebagai santri dengan baik.

Staff pengasuhan santri merupakan kepanjangan dari pengasuh yang turut berkontribusi secara struktural terhadap proses internalisasi nilai-nilai pesantren di asrama. Bagian pengasuhan santri merupakan induk dari berbagai organisasi santri baik itu OSDA, Pramuka, Kelompok Bahasa, Olahraga, kedaerahan dan secara tidak langsung ke asrama. Bagian ini bertanggungjawab pada keterlaksanaan kegiatan di luar sekolah, atau bisa dikatakan jam kosong. Fungsinya terkait internalisasi nilai adalah memastikan agar segala kegiatan di pondok tidak terlepas dari nilai-nilai dan falsafah pesantren. Para staff menjadi teladan, pelaksana, dan pengawas bagi para santri terhadap implementasi nilai-nilai dan falsafah pesantren.

OSDA merupakan organisasi santri yang turut berperan dalam melaksanakan berbagai kegiatan pondok agar terlaksana dengan baik, dan mencapai target-target tujuan pesantren. OSDA sering berhubungan dengan pengurus asrama atau dikenal dengan mudabbir/ah, terutama pada bidang kebersihan dengan Bagian Kebersihan, keamanan dengan Bagian Keamanan, dan bahasa dengan Bagian Bahasa. Meskipun pada beberapa urusan juga berhubungan dengan bagian-bagian OSDA yang lain. Hubungan tersebut dilakukan dalam rangka memberikan arahan, bimbingan, petunjuk, dan pengawasan agar bidang-bidang tersebut dapat terjaga dan terlaksana dengan baik. Dalam suatu kasus tentang kebersihan, tak jarang pada hari tertentu santri yang bertugas sebagai piket kebersihan tidak 
menjalankan tugas, mudabbir/ah tidak mengingatkan petugas piket. Sehingga bagian Kebersihan OSDA memanggil mudabbir/ah untuk mengidentifikasi masalah kebersihan, dan mengingatkan kembali agar selalu menjaga kebersihan. Pada proses tersebut pemanggilan tersebut, nilai kebersihan menjadi tema penting dalam mengingatkan, dengan harapan bahwa para mudabbir/ah memahami betul manfaat kebersihan dan dampaknya dalam kehidupan berasrama. Selanjutnya, mudabbir/ah memanggil petugas piket dan warga kamar, mengingatkan kembali akan pentingnya nilai kebersihan, yang berimplikasi pada kenyamanan hidup bersama.

Selesai kegiatan tersebut, ketua kamar mengingatkan warga kamar agar senantiasa menjaga kebersihan, sebagaimana slogan yang dituliskan di dinding kamar jadwal piket bersama "an-nadzaafatu min-al-iman". Warga kamar diingatkan kembali tentang urgensi kebersihan, tempat-tempat yang harus dibersihkan, waktu-waktu piket bekerja, alat-alat kebersihan, dan kewajiban setiap individu untuk bertanggungjawab dengan barang-barang yang dimiliki, meletakkan barang-barang pada tempatnya atau di dalam almari. Pada pelaksanaan sehari-hari, di antara para santri mengingatkan petugas piket, juga mengingatkan agar setiap santri bertanggungjawab terhadap kebersihan kamar.

Demikian itu juga berlaku pada nilai-nilai yang lain, yang secara struktural memiliki penanggungjawab dan pengawal untuk memastikan nilai-nilai tersebut difahami, dimengerti, dilaksanakan, dan dipertanggungjawabkan dari tingkat pengurus kamar sampai pada kyai.

\section{Pengarahan Nilai-nilai Pesantren di Asrama}

Pada asrama pesantren, para pengurus menyusun kegiatan harian, mingguan, dan tahunan Kegiatan harian yang dilakukan sehari-hari, umumnya adalah terkait dengan kegiatan kebersihan kamar dan lingkungan asrama, shalat fardhu berjama'ah, pembelajaran bahasa. Kegiatan mingguan dilakukan pada waktu yang lebih panjang, lingkup peserta yang lebih banyak, dan keterlibatan dengan unit lain. Kemudian kegiatan tahunan yaitu kegiatan yang dilakukan selama satu semester sekali, atau bahkan satu tahun sekali. Berbagai kegiatan yang berlangsung di asrama pesantren, mencakup kebersihan, keamanan, kedisiplinan, kemandirian, kebebasan, kasih sayang dan kenyamanan.

Nilai-nilai pesantren disampaikan pada berbagai moment kegiatan di asrama, penyampaian tersebut disampaikan secara verbal dan non-verbal. Secara verbal dilakukan oleh mudabbir/mudabbirah pada saat berkumpul bersama santri saat sore hari dan malam hari menjelang istirahat, kegiatan yang dilakukan adalah pengarahan agar hal-hal yang sudah berjalan untuk ditingkatkan lagi, sebaliknya untuk hal-hal yang tidak berjalan dengan baik, diberikan evaluasi dan arahan agar pada esok hari lebih meningkat lagi. Secara non-verbal dilakukan oleh pengurus asrama dengan keteladanan dalam berbagai kegiatan di asrama. Sebagai contoh, pada kegiatan kebersihan lingkungan asrama yang melibatkan anggota kamar keseluruhan dan dilakukan sore hari, mudabbir/mudabbirah mengumpulkan seluruh anggota kamar, kemudian membagi tugas kepada 2-3 santri untuk membersihkan tempat-tempat tertentu, demikian juga kepada yang lain. Mudabbir/ah pada perkumpulan tersebut menyampaikan banyak hal tentang nilainilai kebersihan dan dampaknya pada seluruh warga asrama. Disampaikan juga bahwa hal-hal yang selaras terhadap apa yang telah mereka pelajari dalam kegiatan sehari-hari adalah budaya pesantren.

Pada malam hari menjelang tidur, para santri dikumpulkan bersama-sama untuk dibacakan daftar hadir yang menandakan bahwa santri tersebut ada di asrama. Sebelum atau sesudah pembacaan absen, pengurus asrama memberikan arahan tentang apa yang telah santri-santri lakukan pada hari tersebut dan mengingatkan untuk bangun malam shalat tahajjud, jikalau esok harinya adalah Senin atau Kamis, pengurus asrama mengingatkan untuk bangun sahur, dan menceritakan fadhilah ibadah-ibadah sunnah.

Pada kegiatan mingguan, bulanan, dan tahunan disampaikan pada saat sebelum kegiatan tentang maksud dan tujuan kegiatan, cara-cara yang dilakukan untuk mencapai tujuan tersebut, dan nilai-nilai yang dapat diambil dan dipelajari dari berbagai kegiatan yang dilakukan. Demikian itu agar difahami oleh para santri bahwa kegiatan yang dilakukan bukan sekedar formalitas atau menggugurkan kewajiban, tetapi ada makna-makna, ada nilai-nilai, dan ada falsafah yang mendorong untuk mensukseskan kegiatan. Secara tidak langsung demikian itu dipelajari oleh para santri, yang kemudian pada saat santri tersebut 
menjadi pengurus, dia akan menyampaikan suatu kegiatan diiringi dengan penjelasan nilai-nilai dan makna yang terkandung di dalamnya.

Dari kegiatan-kegiatan tersebut dapat dimaknai bahwa para pengurus asrama sebagai pengelola dan pemimpin asrama memiliki peranan yang penting dalam menginternalisasikan nilai-nilai pesantren di asrama. Dengan kecakapan mengelola kegiatan, menggerakkan para santri, mengatur tugas-tugas di asrama, memotivasi, mengkomunikasikan ide dan gagasan, dan membangun cara kerja yang baik terkait dengan tanggungjawabnya sebagai pengurus asrama dan bagian dari warga asrama. Sebagai santri, pengurus asrama melakukan proses "uji" relevansi nilai-nilai pesantren terhadap kehidupan bersama di asrama.

\section{Evaluasi Nilai-nilai Pesantren di Asrama}

Dalam kegiatan pendidikan sebagai suatu pola yang tersusun secara sistematis dan bertujuan, mengharuskan proses evaluasi. Hampir mustahil suatu lembaga pendidikan tidak menyelenggarakan kegiatan evaluasi. Implementasi kegiatan-kegiatan yang telah dilakukan, diikuti dengan kegiatan evaluasi proses. Evaluasi proses dilakukan dengan menggunakan barometer keberhasilan kegiatan, proses kegiatan tersebut, dan hal yang penting yaitu implementasi nilai pada santri-santri yang terlibat dalam kegiatan.

Pada kegiatan sehari-hari mudabbir/mudabbirah berkeliling di sekitar asrama mengontrol apa yang dilakukan para santri saat waktu kosong. Pada saat menemukan kegiatan yang positif seperti santri yang menghafal pelajaran, mengerjakan tugas sekolah, atau belajar kelompok, mudabbir/mudabbirah diberikan pujian dan motivasi untuk ditingkatkan, Pada saat menemukan kegiatan yang negative seperti bermain bola dalam kamar, meletakkan alat kebersihan bukan pada tempatnya, bercanda berlebihan, mudabbir/mudabbirah mengingatkan, menasehati, dan memberikan kesadaran dengan acuan nilai-nilai kehidupan di asrama.

Demikian juga dilakukan oleh pengurus OSDA, musyrif/musyrifah, dan guru-guru yang berkeliling di asrama pada sore dan malam hari. Pengawasan dilakukan dengan kesadaran yang tinggi terhadap pentingnya pendampingan para santri pada saat-saat jam kosong (jam di luar sekolah). Secara hirarkis, santri-santri diingatkan oleh mudabbir/mudabbirah, mudabbir/mudabbirah diingatkan oleh OSDA, musyrif/musyrifah, guru-guru, dan kyai.

Output dari evaluasi terhadap kehidupan sehari-hari dituliskan dalam laporan formal dalam raport prilaku sehari-hari yang dikelola oleh guru-guru pengasuhan santri. Laporan tersebut diberikan dalam setiap akhir semester dan akhir tahun pembelajaran. Temuan-temuan akan internalisasi nilai-nilai yang rendah, berdampak pada prestasi belajar yang kurang memuaskan. Sebaliknya, keberhasilan santri dalam menyerap dan mengimplementasikan nilai-nilai pesantren, berdampak pada prestasi belajar yang baik.

\section{PEMBAHASAN}

Hasil temuan penelitian yang dilakukan dengan metode observasi dan wawancara kepada para pengelola asrama dan para santri menunjukkan bahwa internalisasi nilai-nilai pesantren sangat erat kaitannya dengan manajemen asrama. Pola perencanaan nilai-nilai di asrama dilakukan melalui proses visi, misi, 3 pilar dan 9 habit pesantren, yang kemudian diturunkan menjadi kurikulum pondok. Dari kurikulum pondok dipraktekkan dalam kehidupan sehari-hari dengan bentuk sosialisasi nilai-nilai pesantren yang relevan dengan kehidupan di asrama. Pada akhirnya adalah karakter santri yang sopan, santun, tertib, disiplin, mengikuti kegiatan dengan baik, bersosialisasi dengan baik, dan taat terhadap peraturan. Ilustrasi dari pola perencanaan internalisasi nilai-nilai pesantren berbasis asrama adalah sebagaimana pada gambar 1 . 


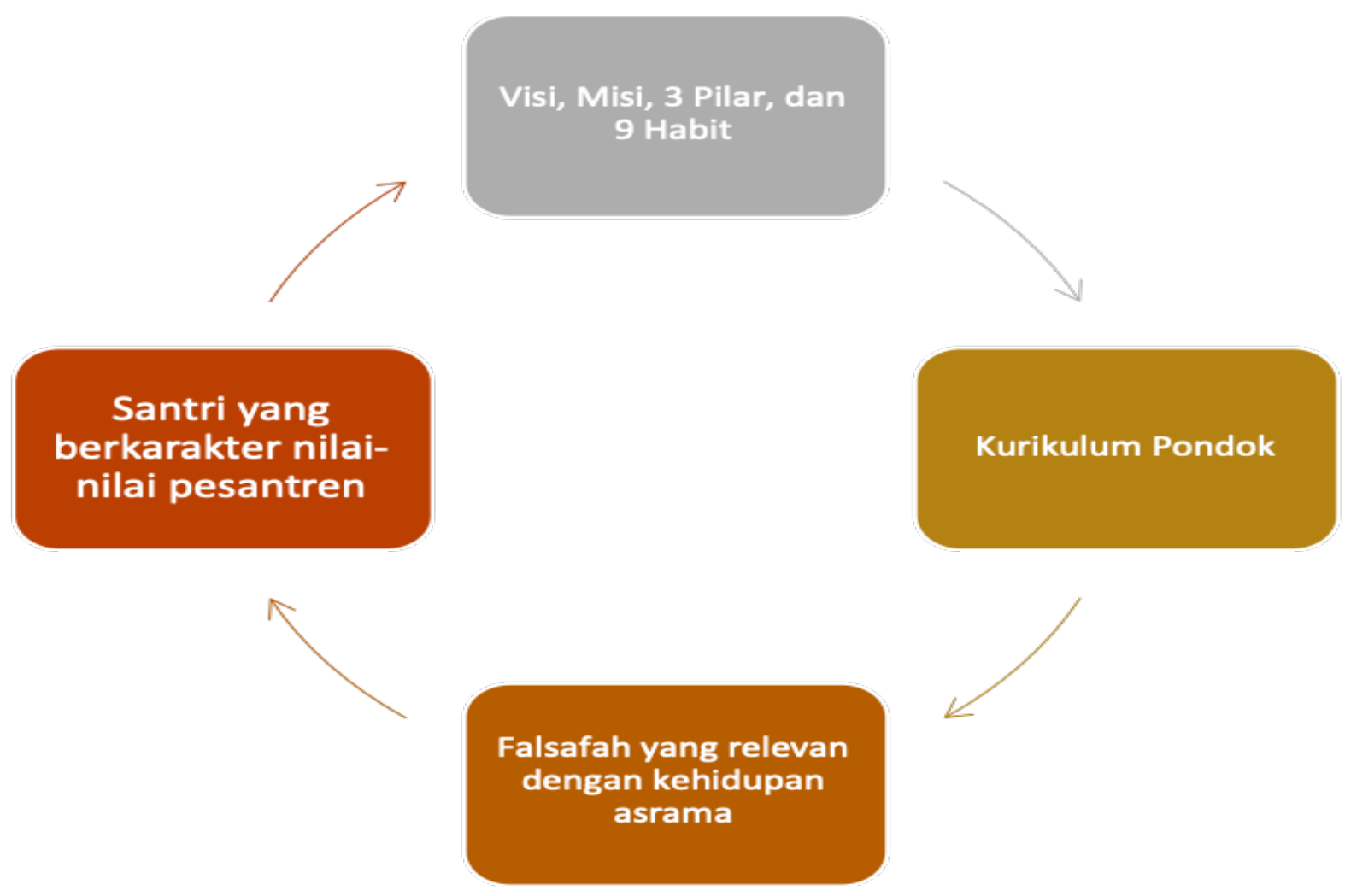

Gambar 1. Pola Perencanaan Internalisasi Nilai-nilai Pesantren

Bagir sebagaimana dikutip Dahlan (2016) mengungkapkan bahwa internalisasi pada tataran konseptual diwujudkan melalui perumusan visi, misi, tujuan, dan program pesantren. Riskiyah dan Muzammil (2020) nilai-nilai akidah, ibadah, akhlaq, dan kemasyarakatan sebagai core value yang diinternalisasikan di pesantren. Nilai-nilai tersebut diperoleh melalui bimbingan, sosialisasi, pengajaran, pengasuhan, pembiasan, dan pengembangan potensi. Dengan nilai-nilai tersebut, dan upaya sosialisasi nilai, diharapakn santri memiliki sikap individu, dan sosial yang baik (Dahlan, 2016; Riskiyah and Muzammil, 2020).

Kurikulum pondok didesain agar para santri memiliki pengetahuan tentang benar dan salah, baik dan buruk, indah dan jelek. Dahlan (2016) menyebutkan bahwa pendidikan karakter di pesantren dilakukan melalui pengkajian Akhlaq lil banin, Akhlaq Nabawi, Mahfudzat, Tafsir, dan Hadits, selain itu juga bersumber dari kitab-kitab kuning dalam tradisi pesantren. Senada dengan hal tersebut, Ma'arif (2018) mengemukakan mata pelajaran untuk nilai-nilai agama dan akhlaq di pesantren yaitu Aqidatul Awam, Ta'lim al-Mut'allim, Al-Qur'an Hadits, Aqidah Akhlaq dan pelajaran Hadits. Pada tahapan ini menurut Lickona sebagaimana dikutip Muhaimin (2005) yaitu tahapan moral knowing, pada tahapan ini disebutkan secara berurutan dari kesadaran moral, pengetahuan nilai-nilai moral, mengambil perspektif, alasan moral, mengambil keputusan, dan pengetahuan diri. Tafsir (2010) mengungkapkan metode internalisasi yang bermula dari knowing (Muhaimin, 2005; Tafsir, 2010; Dahlan, 2016; Ma'arif and Rofiq, 2018).

Praktek di asrama pesantren tidak dimulai dari kesadaran moral, tetapi melalui indoktrinasi pengetahuan nilai-nilai moral, yang kemudian menumbuhkan kesadaran moral. Sebab para santri pada saat kedatangannya membawa prilaku dan pengetahuan masing-masing dari rumah dan lingkungan santri berasal, di sini ada keragaman pengetahuan dan prilaku. Kurikulum pondok baik formal dan informal merupakan alat atau media untuk menggaris bawahi nilai-nilai komunal dalam hidup bersama di pesantren.

Pengorganisasian nilai-nilai pesantren di asrama dilakukan dengan mengoptimalkan struktur organisasi pengelola asrama yang terdiri dari ketua kamar, mudabbir/mudabbirah, musyrif/musyrifah, 
OSDA, Staff Pengasuhan Santri, guru-guru dan Kyai. Para pengurus tersebut merumuskan kegiatankegiatan berdasarkan tujuan pesantren dan nilai-nilai yang terkandung dalam kegiatan tersebut. Tidak dapat dipungkiri bahwa dibutuhkan suatu pola kegiatan yang mengandung nilai sebagai sarana pembiasaan dan aktualisasi nilai-nilai. Selain itu juga para pengurus pondok dan para pembantunya berperan sebagai teladan dalam berbagai kegiatan. Umami dan Amrulloh (2017) mengungkapkan metode internalisasi nilai di pesantren yaitu keteladanan, latihan, dan pembiasaan. Melalui struktur organisasi keteladanan dilakukan oleh figur-figur pengurus dan pengelola pesantren. Latihan diberikan dalam bentuk kegiatankegiatan yang relevan dengan tujuan pesantren. Sedangkan pembiasaan dilakukan dengan kontinuitas kegiatan dalam kegiatan harian, bulanan, dan semester (Umami and Amrulloh, 2017).

Pengarahan nilai-nilai pesantren dilakukan dengan menginsert nilai-nilai dan falsafah pesantren pada saat sebelum dan sesudah kegiatan. Melalui pesan-pesan, nasihat, bimbingan, arahan, dan keteladanan dalam berbagai kegiatan. Dahlan (2016) mengungkapkan bahwa karater santri dibentuk melalui pembiasaan untuk mengabdi, menghormati, menghargai, ikhlas, sederhana, mandiri, yang dirancang selama 24 jam di pesantren. Berbagai karakter tersebut dilakukan melalui pembiasaan, perintah dan larangan, dan keteladanan. Tiga kegiatan internalisasi tersebut dilakukan secara langsung dalam kehidupan bersama di asrama pada berbagai kegiatan (Dahlan, 2016).

Evaluasi nilai-nilai pesantren dilakukan dengan pemberian peringatan untuk hal-hal yang bersifat negative secara langsung ataupun tidak langsung. Secara langsung dalam bentuk teguran dan bahkan hukuman, sedangkan secara tidak langsung diingatkan dalam evaluasi keigatan. Untuk hal-hal yang bersifat positif diberikan motivasi dan dukungan untuk lebih baik lagi. Evaluasi nilai-nilai juga dilakukan dalam format laporan hasil prilaku sehari-hari dalam raport semester yang diberikan kepada wali santri untuk diketahui. Pada proses evaluasi di asrama terdapat proses internalisasi yaitu dengan perintah dan larangan. Perintah dan larangan disampaikan pada saat perkumpulan-perkumpulan warga asrama dan pengurus asrama.

Lickona (2016) mengemukakan bahwa selain moral knowing, terdapat proses moral feeling, dan moral action pada tingkat pengorganisasian nilai, pengarahan nilai, dan evaluasi nilai di asrama. Pada sisi pengurus, moral feeling ditunjukkan dengan status kakak kelas di asrama yang berfungsi untuk menggerakkan para santri agar menjalankan tugas dan tanggungjawab bersama. Moral action ditunjukkan dengan tanggungjawab para pengurus melaksanakan kegiatan dan perencanaannya dalam kegiatan harian, bulanan, dan tahunan. Pada sisi santri, moral feeling ditunjukkan dengan tanggungjawab satu sama lain untuk saling mengingatkan dalam menjaga kebersihan, keamanan, dan kebersamaan hidup damai di asrama. Sedangkan moral action ditunjukkan dengan menjalankan tugas, kewajiban, dan hak hidup bersama di asrama. Demikian itu selaras dengan pendapat Tafsir (2010) menyebutkan aspek doing dan being yang menjadi instrumen internalisasi nilai-nilai juga dilakukan di asrama oleh para pengurus dan santri-santri (Tafsir, 2010; Lickona, 2016).

Suriasumantri (2017) mengungkapkan bahwa dalam membentuk karakter dilakukan dua pola yang utama yaitu; menentukan nilai-nilai, dan mengorganisasikan nilai (Suriasumantri, 2017). Di asrama pesantren, nilai-nilai dan falsafah yang didapatkan oleh para santri dari visi, misi, tujuan, nilai, dan kurikulum pesantren dipilih oleh para pengurus dan warga asrama yang selaras dengan kehidupan di asrama. Pengorganisasian nilai dilakukan oleh pengurus asrama dilakukan dengan pendekatan berbasis manajemen asrama.

Kegiatan manajerial untuk internalisasi nilai-nilai turut memberikan manfaat bagi pengelolaan asrama pesantren, pada aspek perencanaan akan memberikan kejelasan arah dan tujuan bagi warga asrama agar tidak bertentangan dengan visi, misi, tujuan, dan nilai-nilai pesantren secara umum, juga agar dapat mencapai tujuan asrama secara efektif dan efisiein. Aspek pengorganisasian akan memberikan kejelasan tugas, pengelompokan pekerjaan, hirarki tanggungjawab, pengambilan keputusan (reward and punishment), dan penanggungjawab kelompok dan kegiatan. Aspek pengarahan, akan memberikan manfaat motivasi untuk selalu taat dan patuh pada kelompok, juga menjaga kedekatan antara warga asrama. Aspek evaluasi, memberikan suatu informasi atas keterlaksanaan kegiatan kelebihan dan kekurangannya. 


\section{SIMPULAN DAN SARAN}

\section{Simpulan}

Internalisasi nilai-nilai pesantren berbasis manajemen asrama merupakan hal yang turut membantu pesantren dalam menjaga kebersamaan warga pesantren, dan memfilter nilai-nilai baru yang datang dari luar pesantren secara efektif dan efisien. Internalisasi berbasis manajemen asrama dilakukan secara holistic dengan membaca visi, misi, tujuan, dan nilai-nilai pesantren, yang kemudian diidentifikasi dan dianalisis untuk dijadikan pedoman dalam bentuk visi, misi, tujuan, dan nilai-nilai di asrama. Pengorganisasian nilai-nilai dilakukan oleh pengurus asrama, musyrif/musyrifah, OSDA, Staff Pengasuhan Santri, guruguru, dan kyai yang turut merumuskan kegiatan-kegiatan di asrama dan lingkungannya. Pengarahan dilakukan dengan memberikan bimbingan, keteladanan, reward and punishment, terhadap para santri dan kegiatan yang mereka lakukan. Kemudian evaluasi nilai-nilai pesantren dilakukan secara langsung dalam kehidupan sehari-hari dalam bentuk pesan, nasehat, dan bimbingan. Adapun secara tidak langsung, dituliksan dalam raport akhir semester yang disampaikan kepada para wali santri.

\section{Saran}

Kepada peneliti selanjutnya dapat mengembangkan penelitian ini secara mendalam pada manajemen asrama, dan secara meluas pada faktor-faktor eksternal asrama yang turut berperan dalam menciptakan lingkungan yang kondusif di pesantren. Kepada pengelola pesantren agar memilih nilai-nilai pesantren yang lebih spesifik sebagai karakter pendidikan di asrama yang kemudian diorganisasikan dalam manajemen asrama.

\section{DAFTAR RUJUKAN}

Afandi, R. (2013) 'EFEKTIFITAS KEPEMIMPINAN TRANSFORMASIONAL PESANTREN BAGI PENINGKATAN MUTU LEMBAGA PENDIDIKAN ISLAM', Jurnal Kependidikan, 1(1).

Akbar, A. and Ismail, H. (2018) 'Metode Pembelajaran Kitab Kuning di Pondok Pesantren Daarun Nahdhah Thawalib Bangkinang', Al-Fikra: Jurnal Ilmiah Keislaman, 17(1).

Arifin, Z. (2015) 'Budaya Pesanren dalam Membangun Karakter Santri', Sekolah Tinggi Agama Islam (STAI) AlQodiri Jember, 4(2). Available at: http://ejournal.kopertais4.or.id/index.php/qodiri/index.

Bawani, I. (2016) Metodologi Penelitian Pendidikan Islam. Sidoarjo: Khazanah Ilmu Sidoarjo.

Bruinessen, M. Van (1999) Kitab Kuning, Pesantren dan Tarekat; Tradisi-Tradisi Islam di Indonesia. Bandung: Mizan.

Chandra, P. (2019) 'Internalisasi Nilai-nilai Karakter dalam Tradisi Pondok Pesantren', Nuansa, XII(20), pp. 6480 .

Cresswell, J. W. (2014) Research Design; Pendekatan Metode Kualitatif, Kuantitatif, dan Campuran. Yogyakarta: Pustaka Pelajar.

Dahlan, M. Z. (2016) 'Internalisasi pendidikan karakter di Sekolah', Jurnal Lisan Al-Hal, 7(1), pp. 155-172.

Dhofier, Z. (2011) Tradisi Pesantren: Studi Pandangan Hidup Kyai dan Visinya Mengenai Masa Depan Indonesia. Jakarta: LP3ES.

Drucker, P. F. (2008) Management. Revised Ed. New York: HarperCollins e-books.

Hanani, N. (2017) 'Manajemen pengembangan pembelajaran kitab kuning', Realita, 15(2), pp. 1-25.

Isnaini, M. (2013) 'Internalisasi Nilai-Nilai Pendidikan Karakter Di Madrasah', AL-Ta lim, 20(3), p. 445. doi: 10.15548/jt.v20i3.41.

Kesuma, G. C. (2017) 'Pesantren Dan Kepemimpinan Kyai', Terampil : Jurnal Pendidikan dan Pembelajaran Dasar, 1(1), pp. 99-117. doi: 10.24042/TERAMPIL.V1I1.1308.

Lickona, T. (2016) Educating for character: Mendidik untuk membentuk karakter. Jakarta: Bumi Aksara.

Ma'arif, M. A. and Rofiq, M. H. (2018) 'Pola Pengembangan Kurikulum Pendidikan Pesantren Berkarakter : Studi Implementasi Pendidikan Berkarakter di Pondok Pesantren Nurul Ummah Mojokerto Muhammad Anas Ma ' arif, Muhammad Husnur Rofiq Abstrak Pendahuluan Pondok Pesantren merupakan suatu lembaga', Jurnal Tadris, 13(1), pp. 1-16. 
Mardiyah (2012) 'Kepemimpinan Kiai dalam Memelihara Budaya Organisasi', TSAQAFAH. Vol. 8(No.1), pp. $67-104$

Masrur, M. (2018) 'Figur Kyai dan Pendidikan Karakter di Pondok Pesantren', Tarbawiyah Jurnal Ilmiah Pendidikan, 14(02), pp. 272-282. Available at: http://e-journal.metrouniv.ac.id/index.php/tarbawiyah/article/ view/1022.

Mastuhu (1994) Dinamika Sistem Pendidikan Pesantren. Jakarta: INIS.

Muhaimin, M. (2005) Pengembangan Kurikulum Pendidikan Agama Islam. Jakarta: P.T. Rajagrafindo Persada.

Nashori, F. (2011) 'Kekuatan Karakter Santri', Millah, 11(1), pp. 203-219. doi: 10.20885/millah.vol11.iss1.art10.

Perawironegoro, D. (2018) 'Hubungan antara Struktur Organisasi, Budaya Organisasi, dan Manajemen Sumber Daya Manusia dengan Efektifitas Organisasi di Pondok Modern Darussalam Gontor Ponorogo’, Disertasi Manajemen Pendidikan Islam Universitas Islam Maulana Malik Ibrahim Malang.

Perawironegoro, D. (2019) 'Manajemen Asrama di Pesantren', Tadbir, 3(2), pp. 129-144.

Pertiwi, A. K. et al. (2018) 'Analisis Interaksi Simbolik Kyai Dan Santri Dalam Perspektif Kepemimpinan Berbasis Nilai Dan Etika', Jurnal Manajemen dan Supervisi Pendidikan, 2(3), pp. 185-191. doi: 10.17977/ um025v2i32018p185.

Qomar, M. (2007) Manajemen Pendidikan Islam. Jakarta: Erlangga.

Rasyidin, A. (2017) 'Pembelajaran Kitab Kuning Di Pesantren Musthafawiyah, Mandailing Natal', Journal of Contemporary Islam and Muslim Societies, 1(1), pp. 41-67. doi: 10.30821/jcims.v1i1.324.

Rijal, A. S. (2017) 'Pemakaian Kitab Kuning Dalam Meningkatkan Mutu Pembelajaran Fiqh di Madrasah Tsanawiyah Berbasis Pesantren di Pamekasan', Muslim Heritage: Jurnal Dialog Islam dengan Realitas, 2(2).

Riskiyah, I. and Muzammil, M. (2020) 'Internalisasi Nilai-nilai Keislaman dalam Pendidikan Pesantren di Pondok Pesantren Nurul Qur'an Karanganyar Paiton Probolinggo', Edisi: Jurnal Edukasi dan Sains, 2(1), pp. 25 -39.

Schein, E. H. (2004) Organizational Culture and Leadership. San Francisco. 3rd Editio. San Fransisco: JosseyBass. doi: 10.1080/09595230802089917.

Setiawan, E. (2013) 'MODERNISASI POLA SISTEM PENDIDIKAN PESANTREN (Studi Kasus Pondok Pesantren Modern Daarul Fikri Mulyoagung Dau Malang)', ULUL ALBAB Jurnal Studi Islam, 14(2). Available at: http://ejournal.uin-malang.ac.id/index.php/ululalbab/article/view/2656.

Sri Wahyuni Tanshzil (2012) 'Model Pembinaan Pendidikan Karakter Pada Lingkungan Pondok Pesantren dalam Membangun Kemandirian dan Disiplin Santri (Sebuah Kajian Pengembangan Pendidikan Kewarganegaraan)', Penelitian Pendidikan. Available at: http://jurnal.upi.edu/penelitian-pendidikan/view/1848/MODEL PEMBINAAN PENDIDIKAN KARAKTER PADA LINGKUNGAN PONDOK PESANTREN DALAM MEMBANGUN KEMANDIRIAN DAN DISIPLIN SANTRI (Sebuah kajian pengembangan Pendidikan Kewarganegaraan).

Sufa, A. F. (2017) 'Efektifitas Metode Pembelajaran Kitab Kuning Di Madrasah Diniyah Pondok Pesantren AlMahalli Brajan Wonokromo Pleret Bantul Tahun Ajaran 2013/2014', LITERASI (Jurnal Ilmu Pendidikan), 5(2), p. 169. doi: 10.21927/literasi.2014.5(2).169-186.

Suriasumantri, J. S. (2017) Filsafat Ilmu; Sebuah Pengantar Populer Keterkaitan Ilmu, Agama, dan Seni. Jakarta: P.T. Sinar Harapan.

Syafe'i, I. (2017) 'PONDOK PESANTREN: Lembaga Pendidikan Pembentukan Karakter', Al-Tadzkiyyah: Jurnal Pendidikan Islam, 8(1), p. 61. doi: 10.24042/atjpi.v8i1.2097.

Syarifuddin, Mardianto, D. A. P. (2017) 'Implementasi Program Pendidikan Asrama Dalam Meningkatkan kecerdasan Spiritual Santriwati di Asrama Bahasa Arab Hubbul Wathan Medan’, At-Tazakki, 1(1), pp. 101121.

Tafsir, A. (2010) Filsafat Pendidikan Islami; Integrasi Jasmani, Rohani, dan Kalbu. Bandung: P.T. Remaja Rosdakarya.

Tampubolon, I. (2019) 'Trilogi Sistem Pendidikan Pesantren Muhammadiyah: Suatu Pengantar', Al-Muaddib : Jurnal Ilmu-Ilmu Sosial \& Keislaman, 4(1), p. 116. doi: 10.31604/muaddib.v1i1.797.

Thoriqussu 'ud, M. (2012) 'Model-Model Pengembangan Kajian Kitab Kuning Di Pondok Pesantren', At-Tajdid : Jurnal Ilmu Tarbiyah, 1(2), pp. 225-239. Available at: http://ejournal.stitmuh-pacitan.ac.id/index.php/ attajdid/article/view/13

Umami, S. R. and Amrulloh, A. (2017) 'Internalisasi Nilai-Nilai Pedidikan Akhlak Santri Putri Asrama X Hurun Inn Pondok Pesantren Darul 'Ulum Jombang', Jurnal Pendidikan Islam, 1(1), pp. 112-129.

Wibowo, A. . (2014) 'Internalisasi Nilai-nilai Karakter Bangsa Melalui Mata Pelajaran PAI pada SMA Eks RSBI di Pekalongan’, Analisa, 21(2), p. 291. doi: 10.18784/analisa.v21i02.22. 